\title{
Feasibility Building Structures of PT. Suri Tani Pemuka Cirebon
}

\author{
Arief Firmanto \\ Faculty of Engineering, Gunungjati Swadaya University Cirebon \\ Email: firmanto@yahoo.co.id \\ ${ }^{*}$ Corresponding Author
}

How to Cite : Firmanto, A. (2019). Feasibility Building Structures of PT. Suri Tani Pemuka Cirebon. International Journal for Educational and Vocational Studies, 1 (6), 637-646

\section{ARTICLE HISTORY}

Received: 19 July 2019

Revised: 13 August 2019

Accepted: 4 September 2019

\section{KEYWORDS}

Feasibility;

Structural Analysis;

Testing;

\section{ABSTRACT}

The condition of the building in the building of PT. Suri Tani Pemuka Cirebon experienced a few problems in building material components such as materials made of steel which have begun to show the presence of corrosion in steel. This is caused, among others, from the negligence of poorly controlled boiler engine settings. thus raising issues regarding eligibility in building structures. This study aims to determine the residual strength, deflection value, and interstory drift in building structure components and to determine the level of structure safety in the existing building conditions. The flowchart is carried out starting with a field assessment then a literature study continues with measurement and analysis assessment, followed by analysis, conclusions and finishing. From visual observation and structure calculation, the structure of plant 1 , plant 2 and warehouse, is still functioning well and is suitable for use as long as there is no corrosion and technical disturbance that occurs.

This is an open access article under the CC-BY-SA license.

\section{INTRODUCTION}

Construction is an activity to build facilities and infrastructure. In a civil engineering field, a construction is also known as a building or infrastructure unit in an area or several areas, construction can also be interpreted as the object of the whole building consisting of structural parts.

Structure is the study of structural problems from materials used for development. Some choices of building materials include steel.

The feasibility analysis of the building structure is carried out on existing buildings that have been damaged due to the use and age of the building. The feasibility analysis of the building structure is very important to do considering the safety of the users of the building.

PT Suri Tani Pemuka Cirebon is one of the companies engaged in the food industry that really requires quality requirements, both in the production process and in the facilities and infrastructure of industrial production.

In order to improve the quality of production, PT Suri Tani Pemuka Cirebon in collaboration with the Faculty of Engineering Unswagati Cirebon conducted a feasibility study on the condition of the buildings in the PT Suri Tani Pemuka Cirebon environment.

\section{METHODS}

In the research process the feasibility analysis of this structure uses regulations and construction standards in Indonesia, with the material compiler as follows:

a) Steel Material

\begin{tabular}{ccc}
\hline NO & Data & Specification \\
\hline 1 & Modulus of Elasticity & $\mathrm{Es}=200.000 \mathrm{MPa}$ \\
\hline 2 & Steel Quality & $\mathrm{BJ}=37$ \\
\hline 3 & Melt Voltage & $\mathrm{Fy}=240 \mathrm{Mpa}$ \\
\hline 4 & Breaking Voltage & $\mathrm{Fu}=370 \mathrm{Mpa}$ \\
\hline
\end{tabular}

b) Structure profile

\begin{tabular}{ccc}
\hline NO & Data & Specification \\
\hline 1 & Plant-1 columns and beams & 350.150 .9 .15 and 250.150.9.15 \\
\hline 2 & $\begin{array}{c}\text { Plant-2 columns and beams } \\
\text { and warehouses }\end{array}$ & 250.125 .10 .19 \\
\hline 3 & $\begin{array}{c}\text { Gording Plant 1, Plan 2 and } \\
\text { warehouse }\end{array}$ & $100.50 .4,5.6,8$ \\
\hline 3 & $\begin{array}{c}\text { Tilt angle of plant 2 \& } \\
\text { warehouse (assuming) }\end{array}$ & $15^{0}$ \\
\hline 4 & $\begin{array}{c}\text { Plant tilt angle 1 } \\
\text { (assumption) }\end{array}$ \\
\hline 5 & Roof coverings & Galvalum \\
\hline
\end{tabular}




\subsection{Research Flow}

The flow of research in the feasibility analysis of the structure of PT. Suri Tani Pemuka Cirebon is as follows:

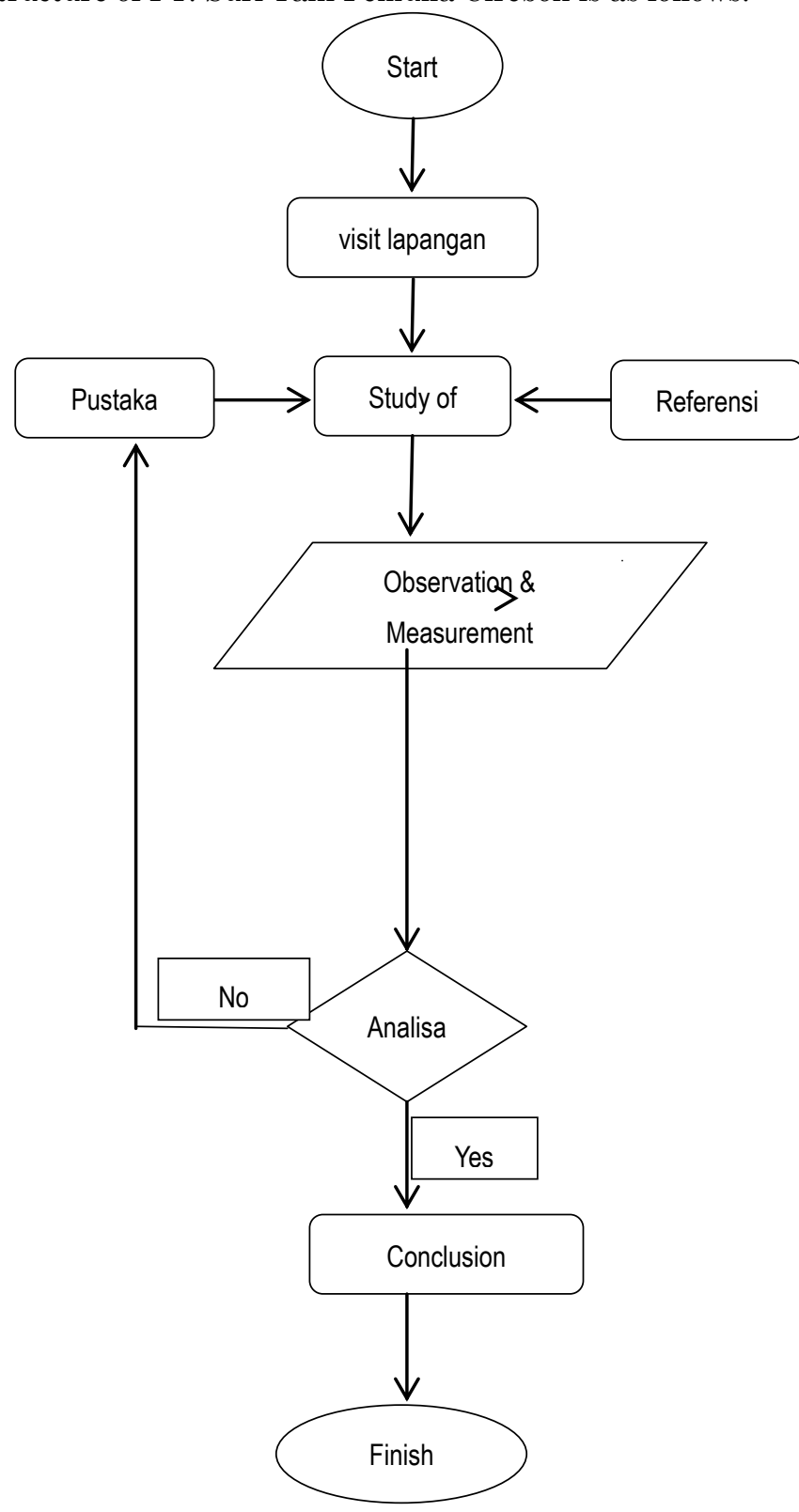

Figure 1. Flow Of Research

\section{RESULTS AND DISCUSSIONS}

\subsection{Effects of Boiler Steam Engines on Steel Profiles}

A boiler is a closed vessel in which combustion heat is flowed into water to form hot water or steam. Hot water or steam at a certain pressure is then used to transfer heat to a process.

A boiler or steam generator that is operated without good water conditions, sooner or later will cause problems relating to buildings, especially materials made of steel.

As a result of lack of handling of boiler feed water will cause the following problems:

\section{Crust Formation}

Crust formed on the bolier wall and the surrounding area occurs due to the formation of crust forming minerals, such as hard ions such as ca2 + and mg2 + and due to the influence of evaporation gas. Besides that it can also be caused by due to heating. Common types of scale in boilers are calcium sulfate, silicate compounds and carbonates.

Substances can form a hard and dense crust so that if it takes a long time to handle it will be very difficult to remove. Silica is deposited together with calcium and magnesium, making the crust harder and harder to remove.

To reduce the occurrence of scale formation on the boiler prevention can be carried out as follows:

a. Reducing the amount of minerals with softener units

b. Make regular blowdowns

c. Provides anti-crust chemicals

\section{Corrosion}

Corrosion can be caused by oxygen and carbon dioxide contained in condensed steam. Corrosion is a metal event that returns to its original form in for example iron to iron oxide, aluminum and others. Corrosion events can occur due to:

a. Corrosive gases such as $\mathrm{O} 2, \mathrm{CO} 2, \mathrm{H} 2 \mathrm{~S}$

b. Crust and deposit

c. Difference of metals (galvanized corrosion)

d. $\mathrm{pH}$ is too low and others

The types of corrosion found in boilers and steam systems are general corrosion, pitting and embrittlement. The presence of dissolved gases, oxygen and carbon dioxide in boiler feed water is a major cause of general corrosion and pitting corrosion (electro-chemical and diffrential oxygen types).

To reduce the occurrence of corrosion events can be done as follows prevention:

a. Reducing gases that are corrosive

b. Prevents scale and deposits from forming in the boiler

c. Prevents galvanized corrosion

d. Using substances that can inhibit corrosive events

Adjust the $\mathrm{pH}$ and alkalinity of boiler water and others.

\subsection{Measurement and Analysis}

Conducting research at PT. Suri Tani Pemuka Cirebon performed the following analysis: 


\subsubsection{Results of Measurement}

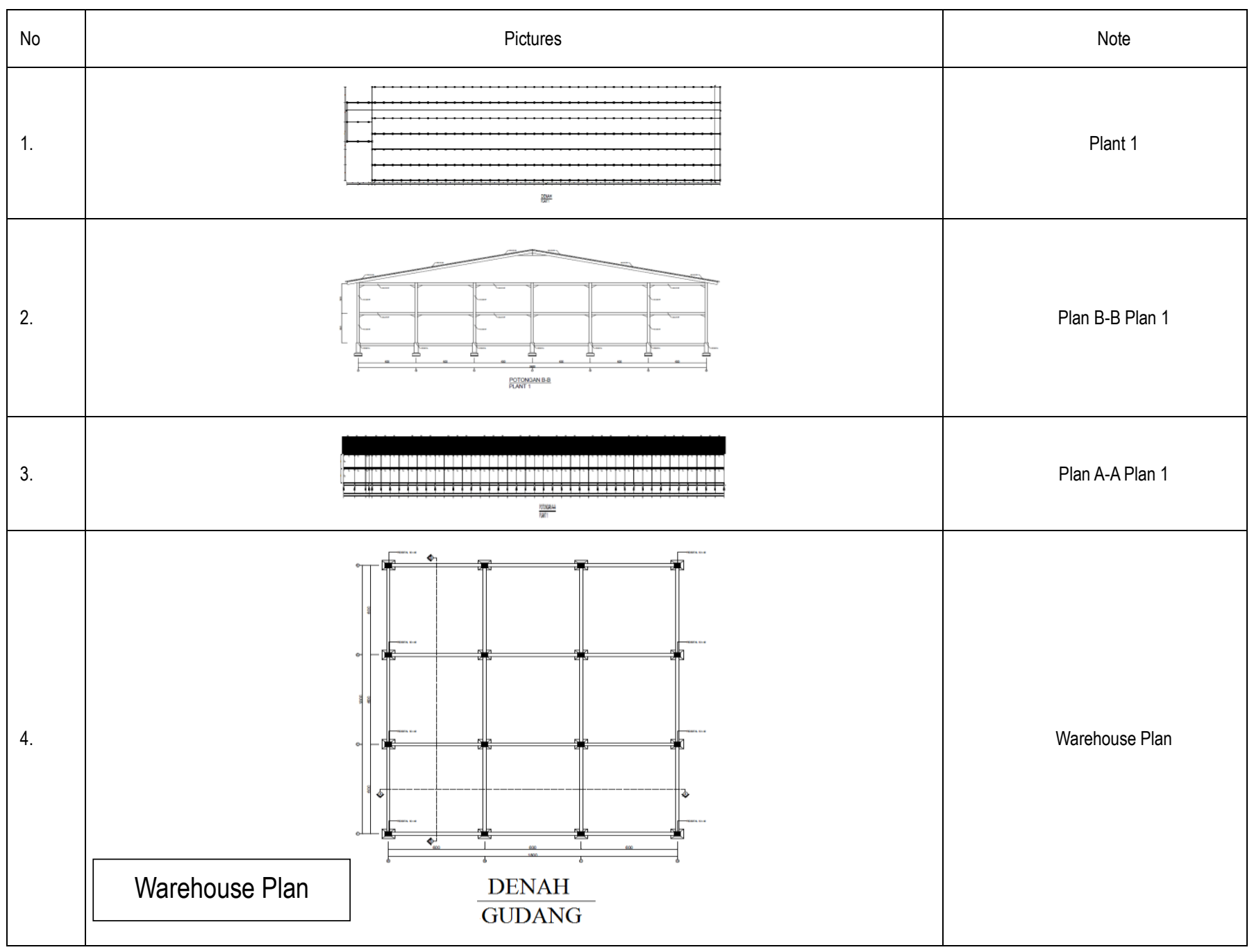

6.




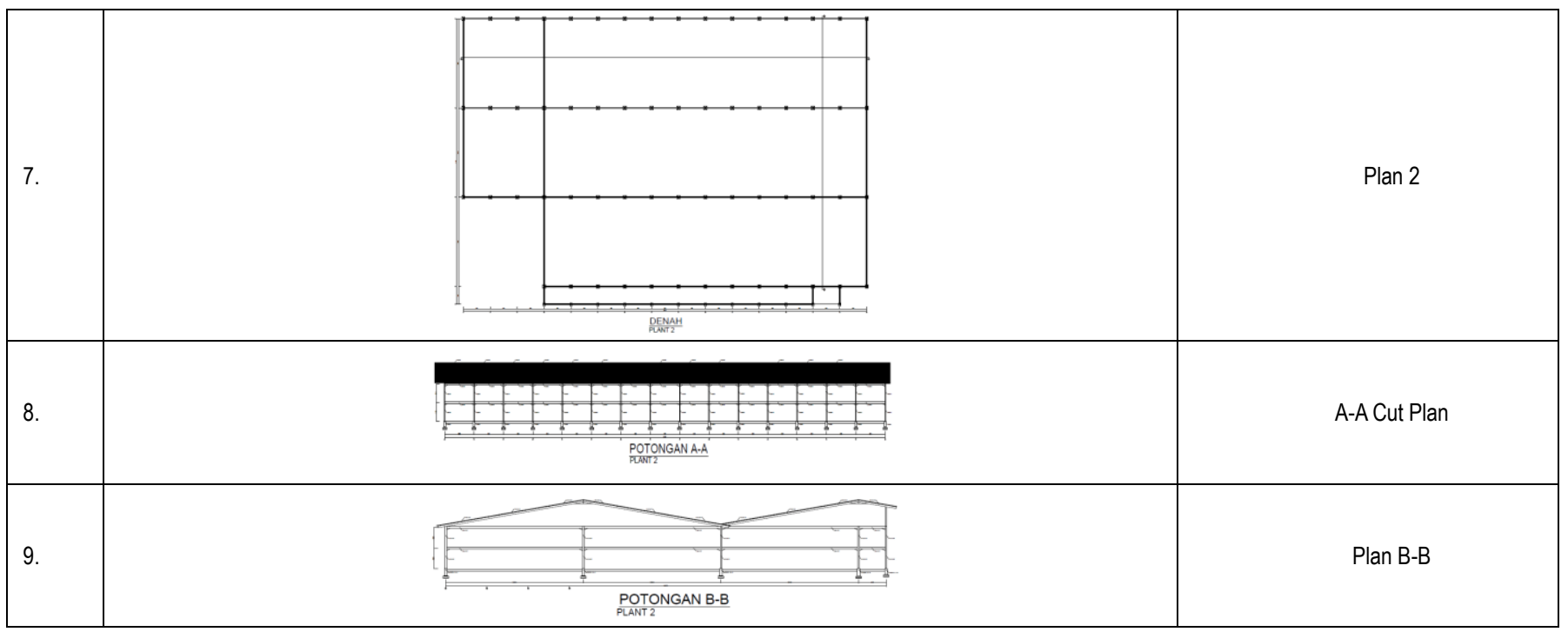

3.2.2 Results of Design Analysis and Loading

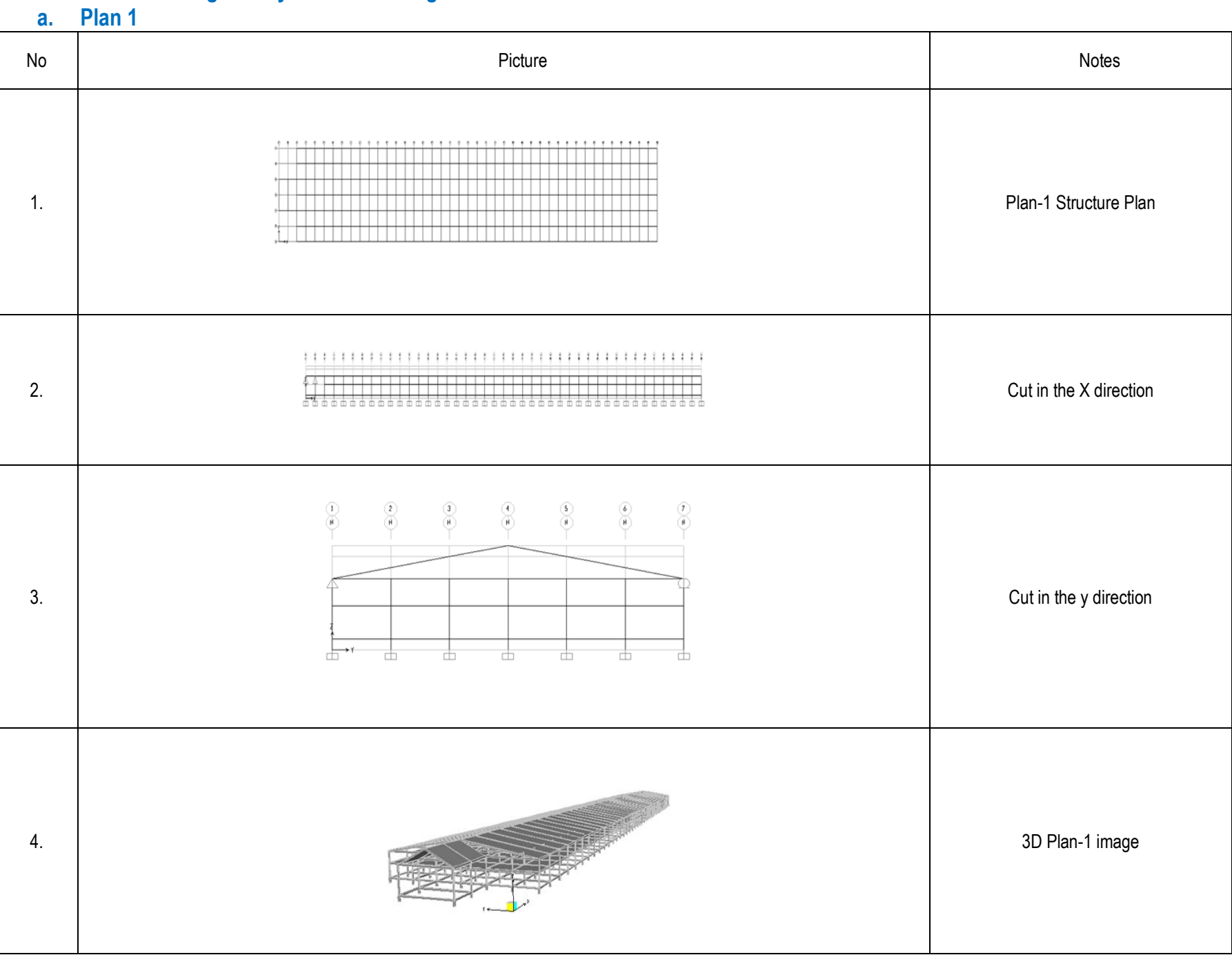




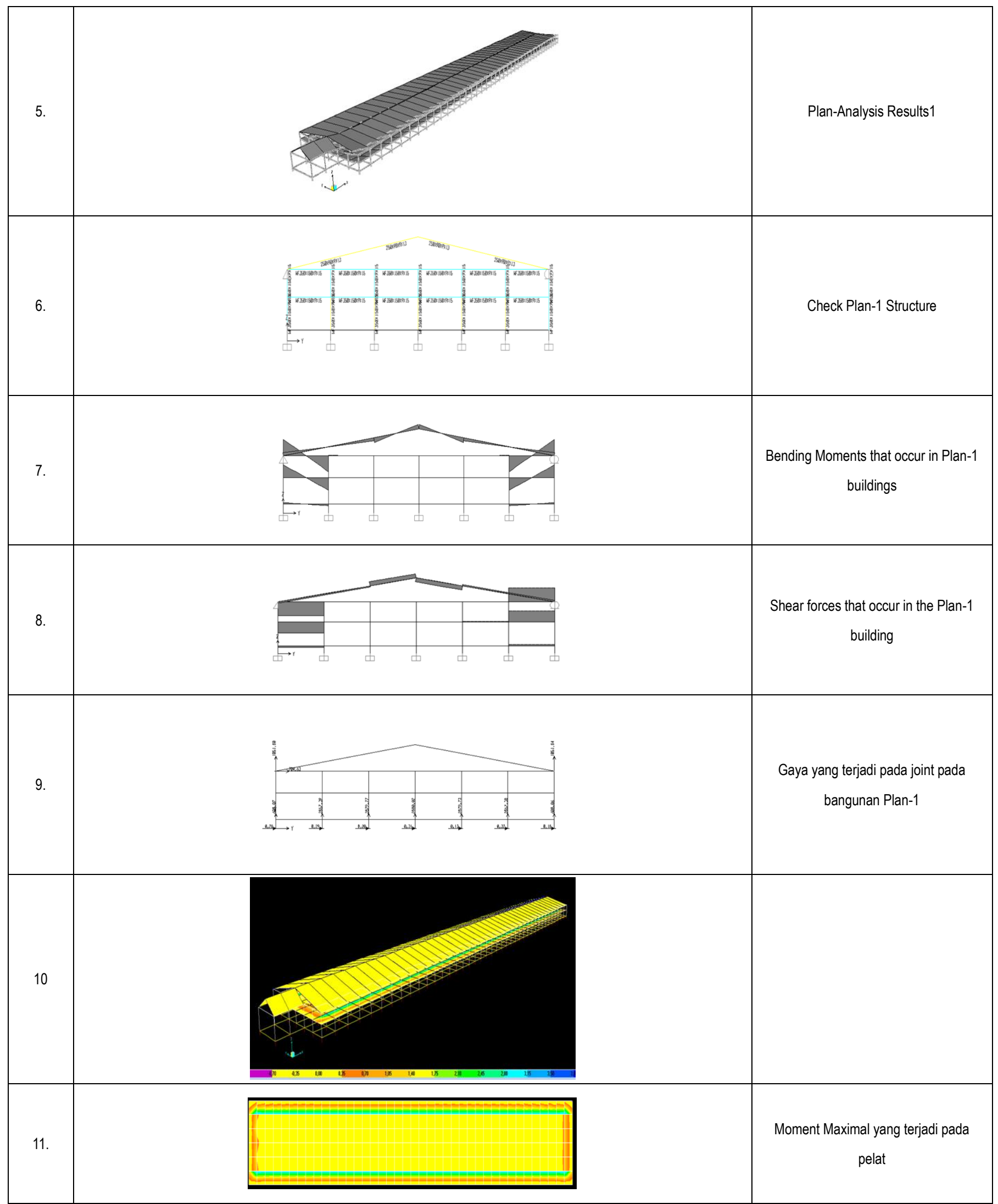




\section{b. Warehouse Building}

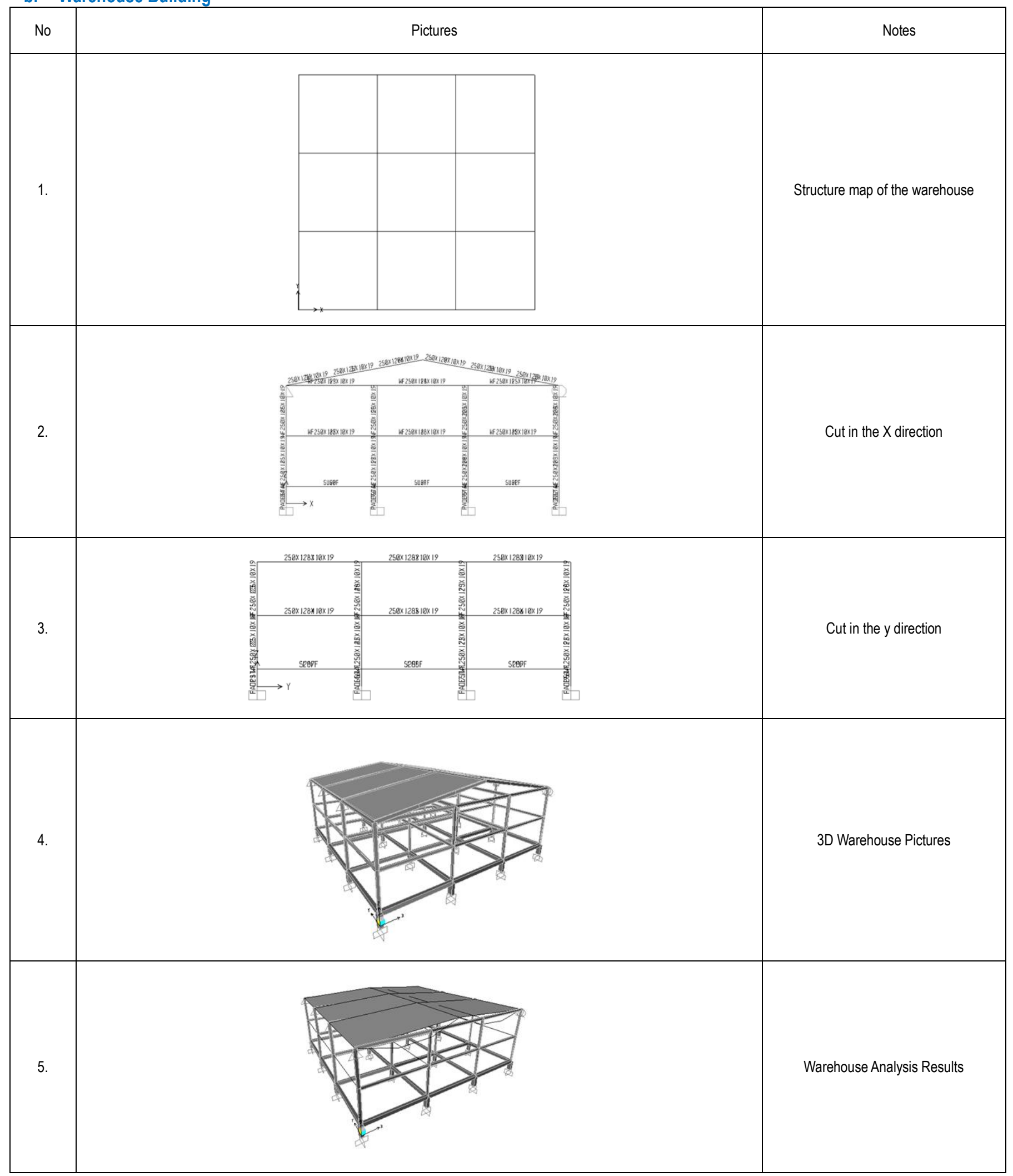




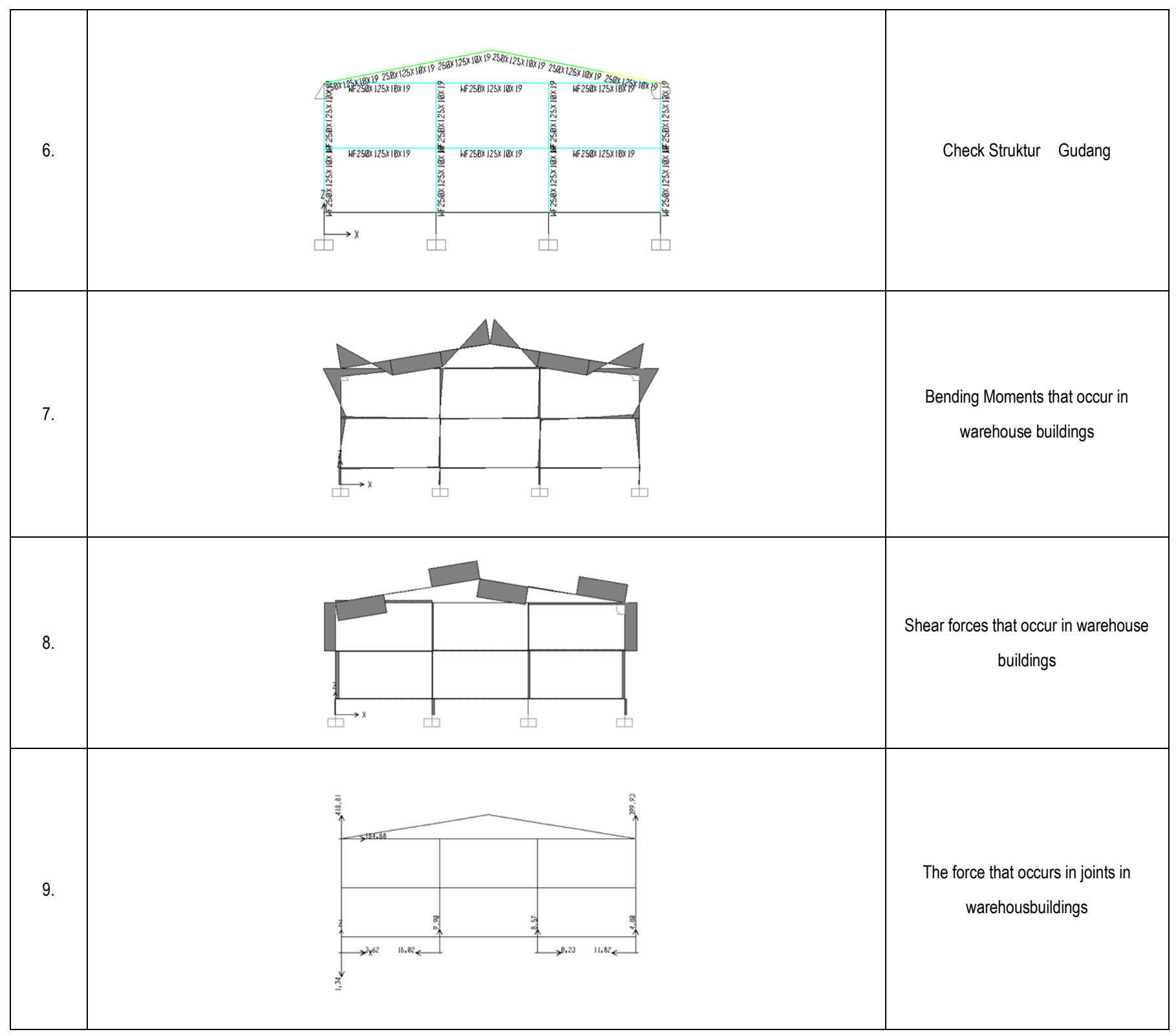

C. Plant 2

\begin{tabular}{|l|l|l|l|l|l|l|l|l|}
\hline No & \multicolumn{10}{|c|}{ Picture } & & \\
\hline \\
1.
\end{tabular}




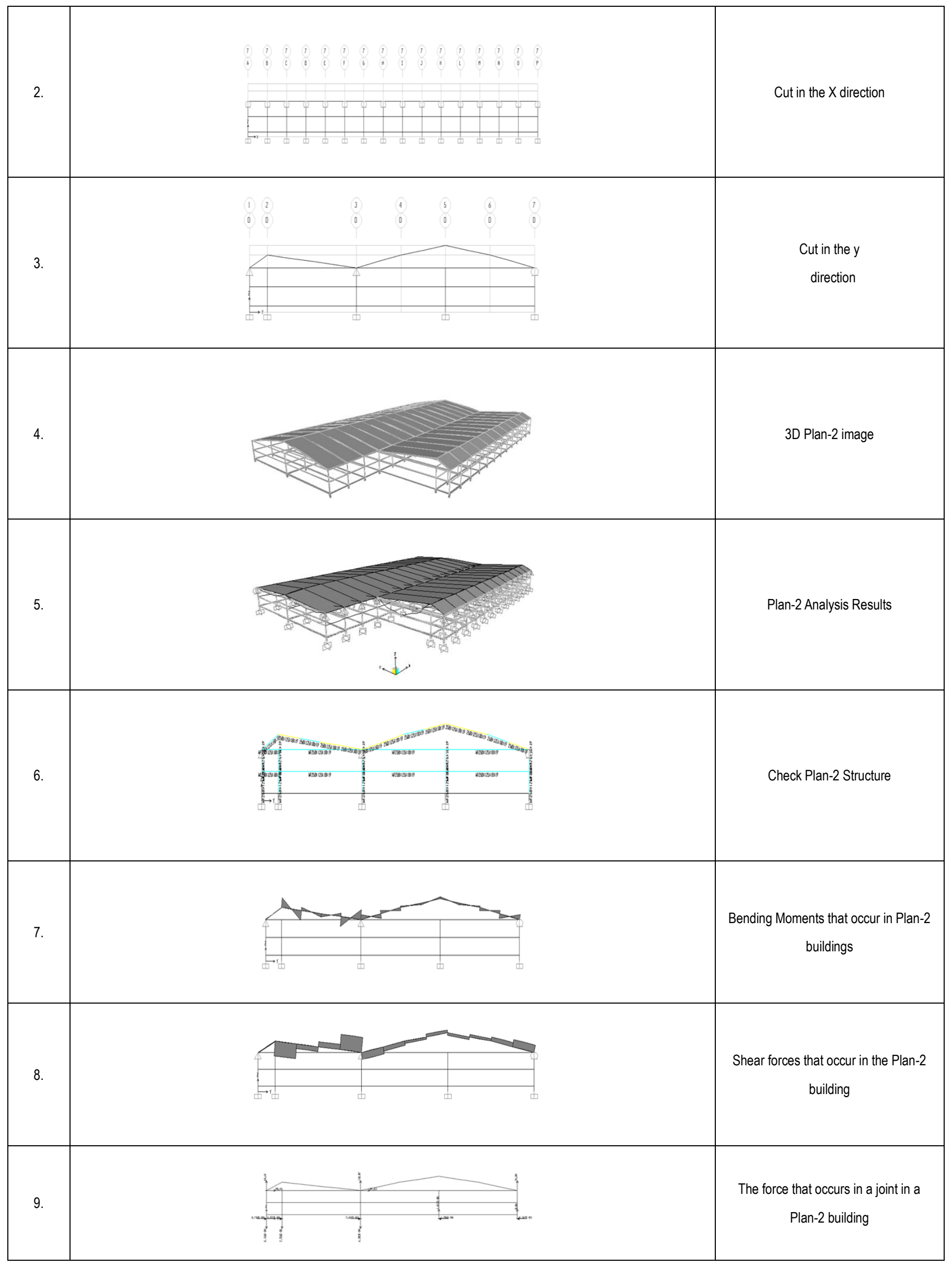




\subsubsection{Visual Observation And Measurement}

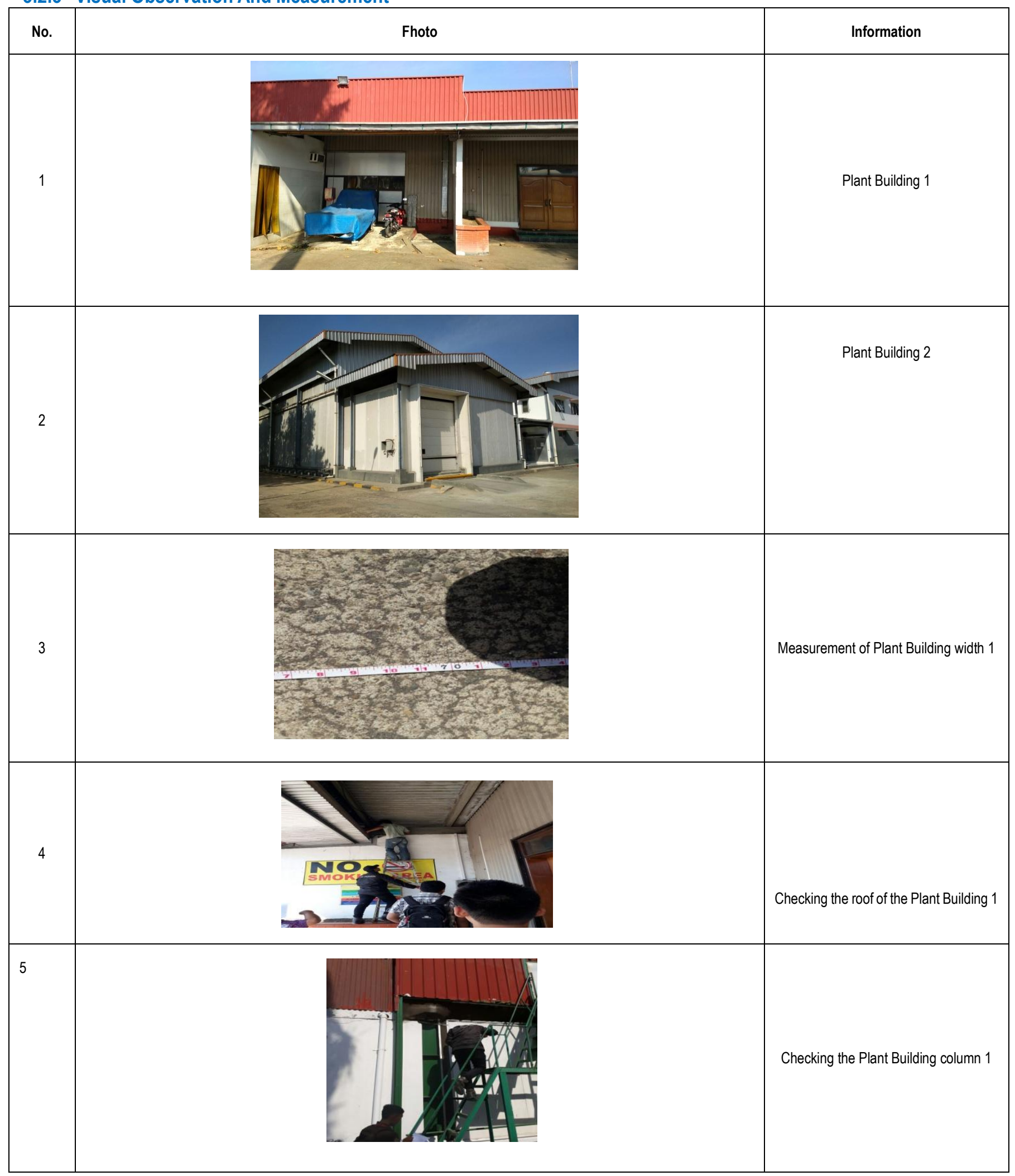

\section{CONCLUSION}

Based on the results of research on the building of PT. Suri Tani Pemuka Cirebon can be concluded as follows:

1. From the analysis of the structure of the Plant-1,
Plant-2 and Warehouse buildings in PT.Suri Tani Pemuka Cirebon using steel construction, the structural profile used has been able to serve the burden that occurs in the Plant-1, Plant-2 and warehouse located PT. Suri Tani Pemuka Cirebon. 
2. From visual observation and structure calculation, the structure of plant 1 , plant 2 and warehouse, is still functioning properly and is suitable for use as long as there is no corrosion and technical disturbance that occurs.

\section{REFERENCES}

Earthquake Resistant Planning Regulations SNI 03-1726 2012

Specifications for Structural Steel Buildings SNI 1729 2015

Structural Concrete Requirements For Buildings SNI 2847 - 2013 Minimum Loading of SNI 1727 - 2013

Guidance for Guidance for Loading and PPURG Buildings 1987.

http://deditutibiokim.blogspot.co.id/2011/12/boiler-dan-jeni s-jenis-boiler.html

Imran, S. Darmawan, I. Sulaiman, C. Lie, Aryantho, 2009, Assessment and Repair / Strengthening of a Settlement Damaged Office Building, Proceedings of the 1st International Conference on Rehabilitation and Maintenance in Civil Engineering (ICRMCE), Solo.

SNI-03-2847-2002. The Procedure for Calculating Concrete Structures for Buildings, Beta Version, Bandung. 